\title{
Development and Evaluation of an ELISA Method for the Determination of Lipoprotein Lipase Mass Concentration - Comparison with a Commercial, One-Step Enzyme Immunoassay
}

\author{
Marjatta Antikainen ${ }^{1,3}$, Leena Suturinkeroinen ${ }^{2}$, Matti Jauhiainen ${ }^{3}$, Christian Ehnholm ${ }^{3}$ and Marja-Riitta Taskinen ${ }^{2}$ \\ 1 Children Hospital, University of Helsinki, Helsinki, Finland \\ 2 Helsinki University Central Hospital, University of Helsinki, Helsinki, Finland \\ 3 Department of Biochemistry, National Public Health Institute, Helsinki, Finland
}

Summary: We developed a non-competitive, enzyme-linked, immunosorbent assay (ELISA) for the quantitation of lipoprotein lipase (LPL) in human postheparin plasma using affinity-purified antihuman milk lipoprotein lipase antibodies produced in chicken eggs and a monoclonal antibody directed against human lipoprotein lipase. We compared our ELISA method with a commercially available sandwich-enzyme immunoassay (Markit-F LPL EIA Kit, Dainippon Pharmaceutical Co, Ltd. Osaka, Japan). The reference values for lipoprotein lipase catalytic activity concentration and mass concentration in healthy Finns were determined. Lipoprotein lipase activity concentration (mean $\pm \mathrm{SD}$ ) was $297 \pm 112 \mathrm{U} / 1$ in women, and mass concentration as measured by the ELISA method was $1058 \pm 367 \mu \mathrm{g} / \mathrm{l}$. The corresponding values for men were $247 \pm 97 \mathrm{U} / 1$ and $815 \pm 207 \mu \mathrm{g} / \mathrm{l}$, respectively. Across the whole concentration range of the ELISA method, the control samples' intra- and inter-assay coefficients of variation $(\mathrm{CV})$ were $5.1 \%$ and $6.5 \%$, respectively. The correlation between the ELISA and EIA methods was good, $\mathrm{r}=+0.81$. The importance of the correct standardisation of immunoassays is discussed.

\section{Introduction}

Lipoprotein lipase (EC 3.1.1.34) plays a central role in lipoprotein metabolism by hydrolysing both dietary and endogenous triacylglycerols transported in chylomicrons and VLDL particles $(1-3)$. Upon hydrolysis, fatty acids are liberated for use in adipose and muscle tissues. Lipoprotein lipase protein is mainly synthesised in adipose tissue, muscles, and lactating mammary glands (4). The mature protein is secreted from parenchymal cells and transported to capillaries, where lipoprotein lipase is bound to glycosaminoglycan components of the capillary endothelium $(5,6)$.

Lipoprotein lipase can be released into the circulation by intravenous injection of heparin, which enables the lipoprotein lipase to be measured in postheparin plasma. An antiserum inhibition method using glycerol tri[1$\mathrm{C}^{14}$ ]oleate as a substrate was the principle method used to measure lipoprotein lipase activity concentration (7). Many immunological approaches for the quantitation of lipoprotein lipase mass concentration in plasma using both poly- and monoclonal antibodies have been reported (8-15). At present, only one commercial kit for the quantitation of lipoprotein lipase mass concentration in plasma is available (Markit-F LPL EIA Kit, Dainippon Pharmaceutical Co, Ltd. Osaka, Japan) (15).

In metabolic studies on patients with lipid disorders, the analysis of lipoprotein lipase activity concentration and

mass concentration are important diagnostic measurements to estimate whether or not the lipid abnormalities result from a defect in the lipoprotein lipase protein structure. In investigating the functional abnormalities of lipoprotein lipase enzyme in genetic dyslipidaemic disorders, selective measurements of activity concentration and mass concentration have provided valuable data on the synthesis and secretion of lipoprotein lipase protein in cell culture systems $(16,17)$.

In this report we describe the immunisation protocol for chickens, the purification of polyclonal anti-human lipoprotein lipase antibodies in chicken eggs, and the development of an enzyme-linked immuno-sorbent assay (ELISA), a non-competitive sandwich method for quantitation of lipoprotein lipase mass concentration in postheparin plasma. The present method developed is an extension to our previously described lipoprotein lipase ELISA assay (14). In this paper we focussed on the methodological details. We also compared our ELISA method with a commercial, one-step sandwich EIA (15), and determined reference values for postheparin plasma lipoprotein lipase mass concentration and activity concentration in healthy Finns. This study confirms the need for international reference materials to be compiled among laboratories and the importance of the correct standardisation of immunoassays. 


\section{Methods}

Purification of human milk lipoprotein lipase

\section{Step 1. Acetone-ether powder of lipoprotein lipase}

Human milk was obtained from the Hunian Milk Bank, University Hospital of Helsinki, and was immediately frozen at $-20^{\circ} \mathrm{C}$. After thawing, the milk was centrifuged at $10000 \mathrm{~g}$ for $30 \mathrm{~min}$, at $+4{ }^{\circ} \mathrm{C}$. The fat cake was separated and delipidated according to the protocol described by Zechmer (17), using a sequential delipidation with cold acetone and diethyl ether. The acetone-ether powder was dried under nitrogen and stored at $-20^{\circ} \mathrm{C}$ before use.

\section{Step 2. Heparin-Sepharose chromatography}

Four grams of acetone-ether powder were extracted for $2 \mathrm{~h}$ at $+4{ }^{\circ} \mathrm{C}$ with $60 \mathrm{ml}$ of $0.1 \mathrm{~mol} / \mathrm{l} \mathrm{NaCl}, 0.05 \mathrm{~mol} / 1 \mathrm{NH}_{4} \mathrm{OH} / \mathrm{NH}_{4} \mathrm{Cl}$ (pH 8.5), containing $2 \mathrm{~g} / 1$ Triton $\mathrm{N}-101,2000 \mathrm{IU}$ aprotinin and 360 $\mu \mathrm{g}$ leupeptin. The mixture was centrifuged at $10000 \mathrm{~g}$ for $30 \mathrm{~min}$ at $+4^{\circ} \mathrm{C}$. Glycerol, $100 \mathrm{~g} /$, and solid $\mathrm{NaCl}$ were added to the supernatant to reach the final concentration of $0.35 \mathrm{~mol} / \mathrm{l} \mathrm{NaCl}$. A heparin-Sepharose column $(28 \times 60 \mathrm{~mm}, 48 \mathrm{ml})$ (Pharmacia, Uppsala, Sweden) was equilibrated with $0.35 \mathrm{~mol} / \mathrm{l} \mathrm{NaCl}, 100 \mathrm{~g} / \mathrm{l}$ glycerol, $5 \mathrm{mmol} / 1$ sodium barbital, $\mathrm{pH} 7.4$ containing $0.5 \mathrm{~g} / \mathrm{l}$ EDTA and $0.5 \mathrm{~g} / 1 \mathrm{NaN}_{3}$. The acetone-ether extract was applied to the column at a flow rate of $1 \mathrm{ml} / \mathrm{min}$. The column was washed in $1 \mathrm{~mol} / 1 \mathrm{NaCl}, 100 \mathrm{~g} / \mathrm{l}$ glycerol, $5 \mathrm{mmol} / 1$ sodium barbital, $\mathrm{pH} 7.4$ containing $0.5 \mathrm{~g} / \mathrm{l}$ EDTA and $\mathrm{NaN}_{3}$ until the UV-absorption $\left(\mathrm{A}_{280}\right)$ of the eluate reached the baseline. Lipoprotein lipase was eluted from the heparin-Sepharose column with a buffer of $2 \mathrm{~mol} / 1 \mathrm{NaCl}$, $100 \mathrm{~g} / \mathrm{l}$ glycerol, $5 \mathrm{mmol} / \mathrm{l}$ sodium barbital, $\mathrm{pH} 7.4$ containing 0.5 $\mathrm{g} / 1$ EDTA and $\mathrm{NaN}_{3}$, and $1 \mathrm{~g} / 1$ Triton $\mathrm{N}-101$. Lipoprotein lipase activity was measured (7), and the active fractions were combined.

\section{Step 3. m-Aminophenylboronic acid (PBA) agarose affinity} chromatography

A PBA-agarose column $(28 \mathrm{~mm} \times 30 \mathrm{~mm}, 24 \mathrm{ml})$ (Sigma, St. Louis, USA) was packed and equilibrated with $10 \mathrm{mmol} / 1$ phosphate, $100 \mathrm{~g} / \mathrm{l}$ glycerol, $1 \mathrm{~mol} / 1 \mathrm{NaCl}$, pH 7.5 containing $2 \mathrm{~g} / 1$ Triton $\mathrm{N}-101$ and $1 \mathrm{mmol} / \mathrm{L}$ EDTA. The pool of combined active fractions from the heparin-Sepharose column was applied onto the PBAcolumn with a flow rate of $1 \mathrm{ml} / \mathrm{min}$. Lipoprotein lipase activity was quantitatively bound to the column as no lipoprotein lipase activity could be measured in either the eluate or in the wash fractions. Lipoprotein lipase protein was eluted with $10 \mathrm{mmol} / \mathrm{l}$ phosphate, $1 \mathrm{~mol} / 1 \mathrm{NaCl}, 200 \mathrm{~g} / 1$ glycerol, $2 \mathrm{~g} / 1$ Triton $\mathrm{N}-101,0.3 \mathrm{~mol} / \mathrm{l}$ sorbitol, $\mathrm{pH} 10$, containing $1 \mathrm{mmol} / 1 \mathrm{EDTA}$ and $0.1 \mathrm{~g} / 1 \mathrm{NaN}_{3}$ (19). The fractions with lipoprotein lipase activity were pooled and stored at $-20^{\circ} \mathrm{C}$.

\section{Step 4. Preparative gel electrophoresis}

Twenty $\mathrm{ml}$ aliquot of $m$-aminophenylboronic acid pool of lipoprotein lipase-active fractions were precipitated using chloroformmethanol (20), and electrophoresis was performed on a homogenous $125 \mathrm{~g} / 1$ SDS-polyacrylamide gel (SDS-PAGE). The protein band was visualised with Serva blue, and the fraction corresponding to a lipoprotein lipase molecular mass was dissected out and eluted overnight with $0.1 \mathrm{~mol} / 1$ Tris- $\mathrm{HCl}, 0.1 \mathrm{mmol} / 1 \mathrm{SDS}, \mathrm{pH} 8.8$ buffer in a tube roller at room temperature.

\section{The purity of lipoprotein lipase}

Samples from each purification step were analysed on a $125 \mathrm{~g} / 1$ SDS-PAGE gel and stained with Coomassie staining, as shown in figure 1A. The same samples were also tested for purity with Western blot analysis using monoclonal antihuman lipoprotein lipase antibody (Oncogene Science, New York, USA) (fig. 1B).

\section{Other methods}

SDS-PAGE was run as described by Laemmli (21). Western blotting was performed according to Towbin et al. (22). Protein concen- tration was determined with the Lowry method (23) using a human serum albumin as a standard.

\section{Production of polyclonal chicken egg antibodies} against lipoprotein lipase

Leghorn hens were immunised at the age of 25 weeks with an initial dose of $50 \mu \mathrm{g}$ of lipoprotein lipase protein emulsified in complete Freund's adjuvant. The animals were injected intramuscularly, followed every second week by booster injections of $50 \mu \mathrm{g}$ lipoprotein lipase protein in incomplete adjuvant. The eggs began to be collected one month after the first antigen injection.

\section{Purification of polyclonal antihuman lipoprotein} lipase antibodies from eggs

The purification of egg immunoglobulins was carried out as described by Jensenius et al. (24). Briefly, the yolk was separated from the white, diluted in Tris buffered saline $(1: 4)$, and centrifuged at $2000 \mathrm{~g}$ for $20 \mathrm{~min}$ at room temperature. The supernatant was mixed with $150 \mathrm{~g} / \mathrm{l}$ Dextran sulphate, $1 \mathrm{~mol} / / \mathrm{CaCl}_{2}$ in Tris buffered saline, left to stand at room temperature for $30 \mathrm{~min}$, and centrifuged at $2000 \mathrm{~g}$ for $20 \mathrm{~min}$. The proteins in the supernatant were precipitated overnight with ammonium sulphate $(300 \mathrm{~g} / \mathrm{l})$ at room temperature. The protein pellet was extracted with $15 \mathrm{mmol} / \mathrm{l}$ Tris- $\mathrm{HCl}, 1 \mathrm{~mol} / 1$ urea, $\mathrm{pH} 8.0$, and solubilised proteins were run through a DEAE-Affi-Gel Blue ${ }^{\circledR}$ column (Bio-Rad, Hercules, California, USA) at a flow rate of $1.0 \mathrm{ml} / \mathrm{min}$. After washing, the bound antibodies were eluted with $15 \mathrm{mmol} / /$ Tris- $\mathrm{HCl}, 1 \mathrm{~mol} / \mathrm{l}$ urea, $\mathrm{pH}$ 8.0. The protein in elution fractions was monitored at $A_{280}$.

Affinity-purification of chicken antihuman lipoprotein lipase antibodies

A 1.0 g cyanogen bromide (CNBr)-activated Sepharose 4B (Pharmacia, Uppsala, Sweden) column was prepared according to the manufacturer's instructions (25). Semi-purified human milk lipoprotein lipase protein $(1 \mathrm{mg})$ was covalently coupled with the gel matrix. The final lipoprotein lipase affinity gel was packed into a $4 \mathrm{ml}$ column.

An aliquot of $5 \mathrm{ml}$ from DEAE-Affi-Gel Blue ${ }^{\circledR}$ chromatography pool was applied through the affinity column at a flow rate of 0.5 $\mathrm{ml} / \mathrm{min}$. The column was washed with phosphate buffered saline until the $A_{280}$ reached the baseline. Immunoglobulins were released with $0.1 \mathrm{~mol} / 1$ glycine, $\mathrm{pH} 2.5$. The eluted fractions were immediately neutralised with $1 \mathrm{~mol} / \mathrm{l}$ Tris- $\mathrm{HCl}, \mathrm{pH}$ 8.5. The $\mathrm{A}_{280}$ peak fractions were pooled. Immunoglobulins were dialysed against phosphate buffered saline and stored at $-20^{\circ} \mathrm{C}$.

\section{ELISA for quantitation of lipoprotein lipase}

A polyclonal, affinity-purified, antihuman lipoprotein lipase antibody of chickens $(5 \mathrm{mg} / \mathrm{l}$ in carbonate buffer, $\mathrm{pH} 9.6)$ was bound to microtitre plates by incubation for $4 \mathrm{~h}$ at $+25^{\circ} \mathrm{C}$. The plates were washed 6 times with phosphate buffered saline, $1 \mathrm{~g} / 1$ bovine serum albumin, $0.5 \mathrm{~g} / 1$ Tween-20 and blocked with phosphate buffered saline, $10 \mathrm{~g} / \mathrm{l}$ bovine serum albumin, $0.5 \mathrm{~g} / 1$ Tween-20 for $2 \mathrm{~h}$ at $+37^{\circ} \mathrm{C}$. After six washes, lipoprotein lipase standards (66, $33,16.5,8.25,4.1,2.1,1.0$, and $0.5 \mu \mathrm{g} / \mathrm{l})$ and lipoprotein lipase samples were added (diluted in phosphate buffered saline, $1 \mathrm{~g} / \mathrm{l}$ bovine serum albumin, $0.5 \mathrm{~g} / \mathrm{l}$ Tween-20) and incubated at $+4^{\circ} \mathrm{C}$ for a minimum of $16 \mathrm{~h}$. The wells were washed six times and monoclonal antihuman-lipoprotein lipase antibody (Oncogene Science, New York, USA) was added in a 1:10000 dilution in phosphate buffered saline, $1 \mathrm{~g} / \mathrm{l}$ bovine serum albumin, $0.5 \mathrm{~g} / 1$ Tween20 and incubated for 3 hours at room temperature. After six washes, biotinylated affinity-purified rabbit anti-mouse antibody (Dako A/S, Glostrup, Denmark, $1: 4000$ in phosphate buffered saline, $1 \mathrm{~g} / \mathrm{l}$ bovine serum albumin, $0.5 \mathrm{~g} / 1$ Tween-20) was added, and the reaction proceeded for $2 \mathrm{~h}$ at $+37^{\circ} \mathrm{C}$. After six washes streptavidin-peroxidase was added (Amersham, Amersham, U.K., $1: 2000$ in phosphate buffered saline, $1 \mathrm{~g} / 1$ bovine serum albumin, $0.5 \mathrm{~g} / \mathrm{l}$ Tween-20) and incubated for $1 \mathrm{~h}$ at $+37^{\circ} \mathrm{C}$. The colour reaction with a substrate 1.2-phenylenediamine dihydrochloride 
(Fluka Chemika, Basle, Switzerland) proceeded for 30 minutes (protected from the light), after which the reaction was halted with $2.5 \mathrm{~mol} / 1 \mathrm{H}_{2} \mathrm{SO}_{4}$. Absorbance at $492 \mathrm{~nm}$ was recorded using ELISA plate reader (labsystems Multiscan MCC/340, Helsinki, Finland).

\section{Markit-F LPL EIA Kit}

The quantitation of lipoprotein lipase was performed according to the manufacturer's protocol (Markit-F LPL ELA Kit, Dainippon Pharmaceutical Co, Ltd., Osaka Japan) (15). The assay is a onestep sandwich immunoassay kit that uses two distinct monoclonal antibodies specific for human lipoprotein lipase: One is an antilipoprotein lipase monoclonal antibody linked to a bacterial cell wall as an insolubilised monoclonal antibody, and the other is a $\beta$ $D$-galactosidase labelled antibody as an enzyme-linked detecting monoclonal antibody. Lipoprotein lipase produced by THP-1 cells (human myelogenous leukaemia cells) is used as a standard. The fluorogenic substrate used is 4-methyl-umbelliferyl- $\beta$ - $D$-galactopyranoside. Fluorescence intensity was measured at an excitation of $365 \mathrm{~nm}$ and emission was measured at $450 \mathrm{~nm}$ using a Perkin Elmer LS-5 Luminescence Spectrometer, London, U.K.

\section{Lipoprotein lipase activity assay}

Lipoprotein lipase activity concentration was measured using the antiserum inhibition method (7).

\section{Subjects}

Sixty-six healthy Finns (38 women, 28 men) were studied. The mean age for women was $43 \pm 6$ years and the mean age for men $42 \pm 8$ years. The volunteers did not use any medication or oral contraceptives. Venous blood samples were drawn after an overnight fast. For lipoprotein lipase activity concentration and lipoprotein lipase mass concentration measurements, venous blood was drawn into chilled tubes containing lithium heparin 15 min after an intra-venous injection of heparin (100 IU/ $\mathrm{kg}$, Huhtamäki, Leiras, Helsinki, Finland). Postheparin plasma samples were stored at $-70^{\circ} \mathrm{C}$ before the measurements.

\section{Statistical methods}

Means, standard deviations (SD), and coefficients of variation (CV) were calculated for the lipoprotein lipase control samples. Pearson's correlation coefficients were calculated to evaluate the degree of linear association between variables, the significance of which was calculated using the paired $t$-test procedure.

\section{Results}

The purity of lipoprotein lipase

The purity of lipoprotein lipase was assessed on a 125 $\mathrm{g} / 1$ SDS-PAGE, as shown in figure 1A. Samples from the individual purification steps were analysed. The heparin-Sepharose chromatography was an efficient step for removing most of the proteins of human milk powder (fig. 1A, lane 2). After heparin-Sepharose chromatography, the active lipoprotein lipase pool fractions from $m$ aminophenyl boronic acid agarose column contained a major contamination protein with a relative molecular weight of about 80000 (fig. 1A, lane 3). Separate attempts were made to remove this protein using gel filtration, phenyl-Sepharose chromatography, and by using salt gradient (from 0.4 to $2 \mathrm{~mol} / 1 \mathrm{NaCl}$ ) in heparinSepharose affinity chromatography, none of which were successful. Therefore, the lipoprotein lipase preparation obtained after the two affinity chromatography steps was concentrated and further purified using a preparative $125 \mathrm{~g} / 1$ SDS-PAGE. The final preparation contained a major band with a relative molecular weight of 58000 , which was identified as lipoprotein lipase using monoclonal anti-lipoprotein lipase antibody in immunoblotting (fig. 1B). This preparation was used as a calibrator standard in the ELISA system (see further: Standardisation of the ELISA method).

During the purification steps, it is possible that human milk lipoprotein lipase protein undergoes structural modifications that affect its immunoreactivity. According to the manufacturer's instructions, the lipoprotein lipase protein delivered in the Markit-F LPL EIA Kit (Dainippon Pharmaceutical C., Ltd. Osaka, Japan) has been produced in THP-1 leukaemia cells and has shown to be immunologically homologous with human postheparin plasma lipoprotein lipase (14). It is, therefore, a good primary standard to calibrate other immunoassays for lipoprotein lipase mass determination. To determine the immunoreactive mass of our purified lipoprotein lipase, its protein concentration was measured by ELISA using the protein delivered as a primary standard in the Markit-F LPL EIA Kit.

\section{Specificity of antihuman antibodies}

The monoclonal antihuman lipoprotein lipase antibody produced by Oncogene Science has been tested by Babirak et al. (11) and has been shown to recognise an epitope present in the C-terminal part of human lipoprotein lipase (12). Specific immunoreactivity of our affinitypurified polyclonal antihuman lipoprotein lipase antibody was tested with Western blot analysis. The affinitypurified antibody reacted with human lipoprotein lipase that was isolated from human milk or postheparin plasma, but it did not react with human hepatic lipase, another lipolytic enzyme released into the circulation by

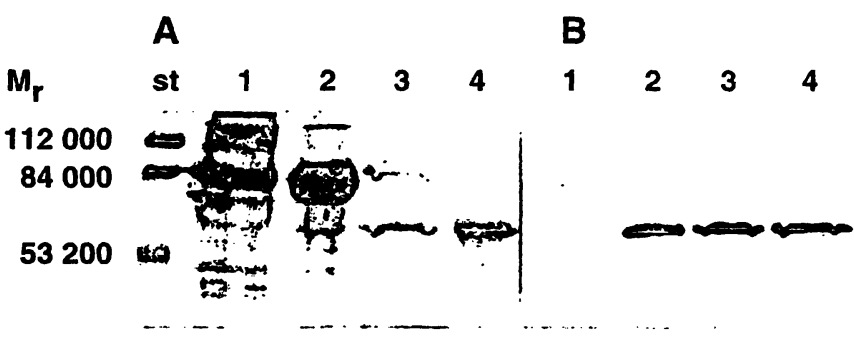

Fig. 1 SDS-polyacrylamide gel (A) and Western blot (B) of the samples from each purification step of the lipoprotein lipase protein.

Lane 1 = delipidated human milk protein in buffer,

lane 2 = pool of lipoprotein lipase active fractions from heparinSepharose column,

lane $3=$ pool of lipoprotein lipase active fractions from $m$-aminophenylboronic acid agarose column,

lane 4 = lipoprotein lipase protein after preparative SDS-PAGE. The gel was stained with Coomassie blue R 250 and Western blot analysis was carried out as described in Methods. Known molecular mass protein markers are shown on the far left. 
intravenous injection of heparin, or with any other serum proteins (data not shown).

\section{Standardisation of the ELISA method}

Figure 2 illustrates the standard curve of the ELISA assay. The preparatively purified lipoprotein lipase was used as a calibrator standard (see above: The purity of lipoprotein lipase). Lipoprotein lipase standard was fractionated into $100 \mu \mathrm{l}$ and stored at $-70^{\circ} \mathrm{C}$. A new aliquot of the standard was thawed for each assay. The standard curve for calibration was obtained by plotting the absorbance at $492 \mathrm{~nm}$ as a function of the standard lipoprotein lipase concentration. The standard curve shows a good response down to $10 \mu \mathrm{g} / \mathrm{l}$, with an ideal working range from $10 \mu \mathrm{g} / 1$ to $50 \mu \mathrm{g} / \mathrm{l}$. Each standard point represents the mean $\pm S D$ of five different measurements.

\section{Stability of standard lipoprotein lipase and postheparin plasma samples}

The effects of freezing at $-70^{\circ} \mathrm{C}$ and thawing on the stability of the lipoprotein lipase standard and human postheparin plasma samples were investigated. The postheparin plasma lipoprotein lipase mass concentration of ten fresh samples were measured and then subsequently subjected to four freezing and thawing cycles. The samples' longest storage time was 12 months. Camparing the fresh and thawed samples, the lipoprotein lipase concentrations of the purified lipoprotein lipase standard and postheparin plasma samples differed by less than $5 \%$. These results indicate that at least four freezingthawing cycles or one year's storage of the samples at $-70^{\circ} \mathrm{C}$ did not affect lipoprotein lipase mass quantitation with the ELISA-method.
The effects of storing the lipoprotein lipase standard and postheparin plasma samples at $+4{ }^{\circ} \mathrm{C}$ were also studied. The mass of the lipoprotein lipase standard remained constant during storage, whereas postheparin plasma lipoprotein lipase mass concentrations varied widely. In most samples, lipoprotein lipase mass levels were higher than in fresh plasma (data not shown). This may indicate that postheparin plasma lipoprotein lipase protein undergoes partial conformational change or degradation during storage at $+4{ }^{\circ} \mathrm{C}$, causing an increased immunoreactivity. It is therefore suggested that the measurement of lipoprotein lipase immunoreactive mass be performed in fresh samples or samples stored at $-70^{\circ} \mathrm{C}$.

\section{Validation of ELISA for lipoprotein lipase mass quantitation}

The validation of ELISA for lipoprotein lipase mass quantitation was examined by precision and sample dilution analysis. Postheparin plasma from five subjects was fractioned into aliquots of $100 \mu \mathrm{l}$ before freezing and were stored at $-70^{\circ} \mathrm{C}$. Five plasma samples were then analysed a total of ten times in the same assay (twice per week for five weeks) to calculate the assay precision. For inter-assay measurements, a new aliquot of postheparin plasma was thawed each time. The mean intra-assay and inter-assay coefficients of variation (CV) for the whole working range of the ELISA assay were $5.1 \%$ and $6.5 \%$, respectively.

Dilution studies were carried out using five different postheparin plasma samples containing high, medium, and low mass concentrations of lipoprotein lipase. All samples were serially diluted $(1: 40,1: 80,1: 160$, $1: 320,1: 640)$. In all samples, linear dose-response

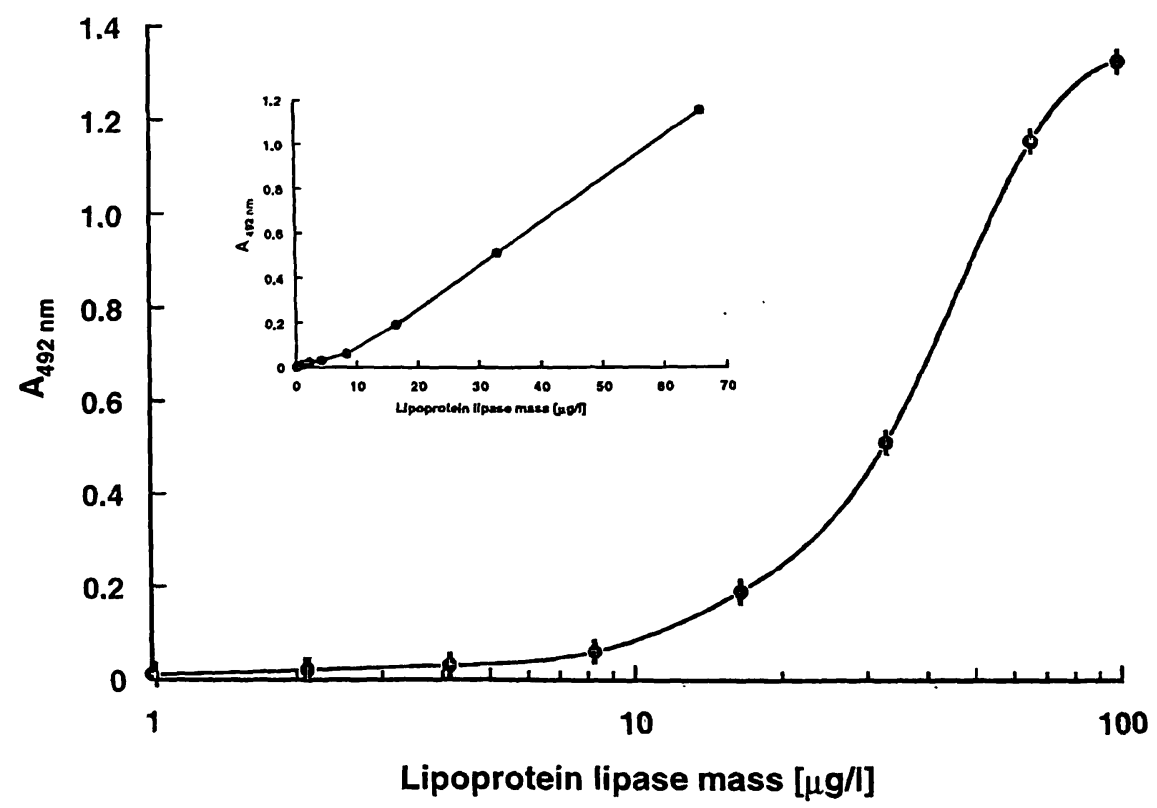

Fig. 2 The ELISA standard curve of lipoprotein lipase mass concentration determination. The immunoreactive mass of lipoprotein lipase was measured by ELISA using a combination of polyclonal

and monoclonal antihuman lipoprotein lipase antibodies. Each point represents the mean $\pm S D$ of five different measurements. Both logarithmic and linear standard curves are presented. 


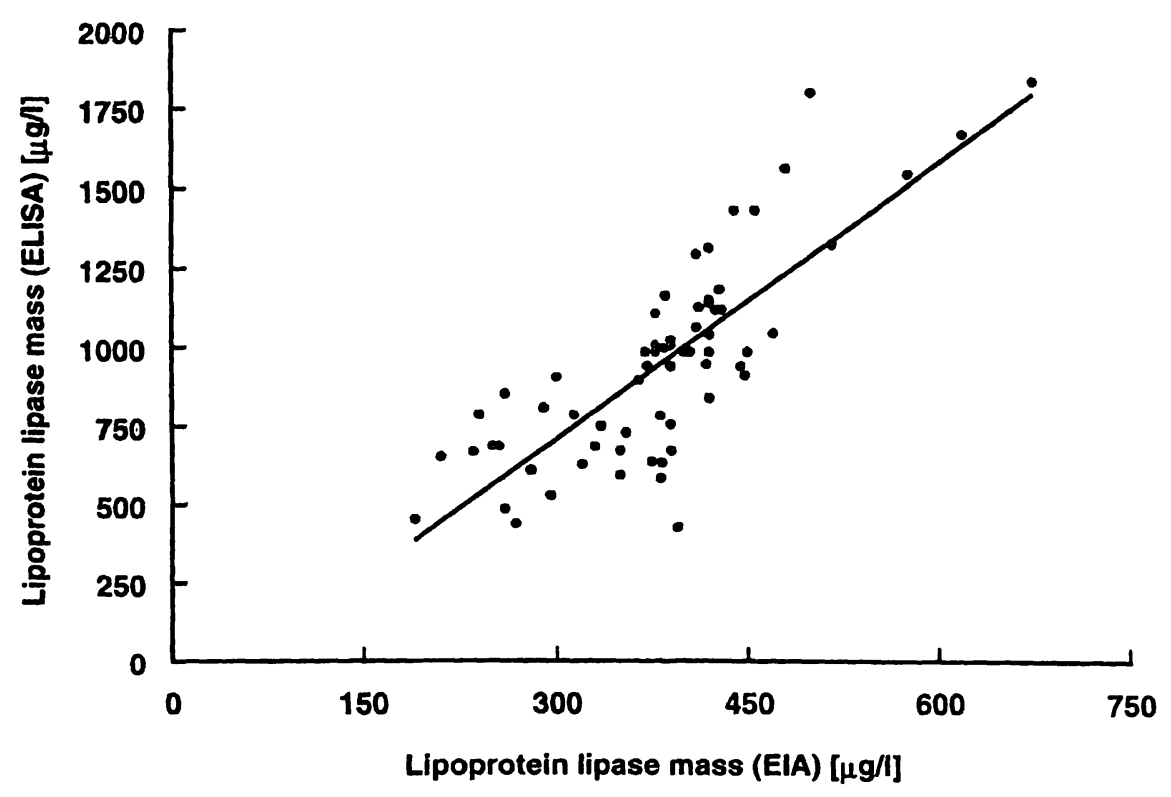

Fig. 3 Regression analysis between the ELISA method and a commercial ELA method. Postheparin plasma samples were analysed and compared.

curves were obtained within the range of standard lipoprotein lipase $(0-70 \mu \mathrm{g} / \mathrm{l})$. The correlation of these measurements was good $(r=0.94 \pm 0.04$, mean $\pm S D)$.

\section{Comparison of ELISA and commercial EIA assays}

The correlation of the two methods was performed by analysing postheparin plasma samples with varying lipoprotein lipase concentrations. The regression between the two techniques has a correlation coefficient of 0.81 , represented by the equation $y=2.58 x+51$ (fig. 3). Accordingly, the correlation was good, although the ELISA method gave significantly higher values than the commercial one.

Lipoprotein lipase protein mass concentration and activity concentration in healthy subjects

Lipoprotein lipase activity concentrations and mass in postheparin plasma in healthy Finns were measured with ELISA and EIA (tab. 1). The values showed no significant differences between genders although women tended to have slightly higher levels. Differences in lipoprotein lipase concentration levels between the two assays is notable and will be discussed. The correlations between lipoprotein lipase activity concentration and mass concentration in healthy Finns $(n=66)$ are shown in figure 4. Panel A represents the ELISA method, and panel $B$ represents the commercial EIA method. A significant, positive correlation existed between lipoprotein lipase activity concentration and mass concentration in both assays (for ELISA, $\mathrm{r}=+0.61, \mathrm{p}<0.001$, for EIA $r=+0.71, p<0.001$ ). To calculate whether the correlation varied for low and high lipoprotein lipase values in the ELISA method, the individuals were divided into groups according to their level of lipoprotein lipase catalytic activity concentration. Group I (low lipoprotein lipase activity concentration) consisted of those subjects with lipoprotein lipase activity concentration below 200 $\mathrm{U} / 1(\mathrm{n}=15)$, and group II (high lipoprotein lipase activity concentration) consisted of the individuals with lipoprotein lipase activity concentration over $300 \mathrm{U} / \mathrm{l}$ $(\mathrm{n}=19)$. In both groups, a significant positive correlation existed $(\mathrm{r}=+0.63, \mathrm{p}<0.01$ for group $\mathrm{I}$, and $r=+0.73, p<0.001$ for group II) between lipoprotein lipase activity concentration and mass concentration.

\section{Discussion}

In the present study we demonstrate the development of the ELISA method for the determination of the immunoreactive mass of lipoprotein lipase in postheparin

Tab. 1 Lipoprotein lipase catalytic activity concentrations and mass concentrations in healthy Finnish subjects.

\begin{tabular}{|c|c|c|c|c|}
\hline & & \multirow{2}{*}{$\begin{array}{l}\text { Lipoprotein lipase } \\
(U / 1)\end{array}$} & \multicolumn{2}{|c|}{ Lipoprotein lipase } \\
\hline & & & ELISA $(\mu \mathrm{g} / \mathrm{l})$ & $\operatorname{EIA}(\mu \mathrm{g} / \mathrm{l})$ \\
\hline $\begin{array}{l}\text { Women } \\
(n=38)\end{array}$ & $\begin{array}{l}\text { mean } \pm S D \\
\text { (range) }\end{array}$ & $\begin{array}{l}297 \pm 112 \\
(79-603)\end{array}$ & $\begin{array}{l}1058 \pm 367 \\
(436-1848)\end{array}$ & $\begin{array}{l}400 \pm 106 \\
(190-675)\end{array}$ \\
\hline $\begin{array}{l}\text { Men } \\
(n=28)\end{array}$ & $\begin{array}{l}\text { mean } \pm S D \\
\text { (range) }\end{array}$ & $\begin{array}{l}247 \pm 97 \\
(97-541)\end{array}$ & $\begin{array}{l}815 \pm 207 \\
(426-1330)\end{array}$ & $\begin{array}{l}362 \pm 70 \\
(210-516)\end{array}$ \\
\hline
\end{tabular}




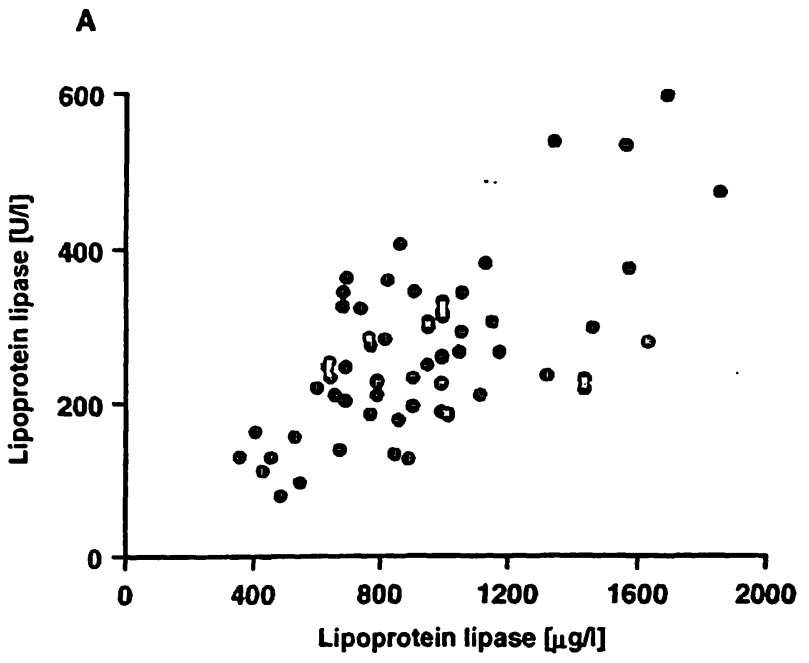

Fig. 4 Correlations of postheparin plasma lipoprotein lipase catalytic activity concentrations (U/l) and mass concentrations $(\mu \mathrm{g} / \mathrm{l})$

plasma. The study describes the immunisation protocol of hens with semi-purified human milk lipoprotein lipase and purification of polyclonal anti-lipoprotein lipase antibodies. The monospecificity of the resulting polyclonal antibody was ascertained by the Western blotting technique.

Purifying of lipoprotein lipase enzyme to homogeneity presents certain problems. The content of lipoprotein lipase in human physiological sources is very low. The use of human milk as lipoprotein lipase enzyme source is justified since human milk is rich in lipoprotein lipase enzyme (18). The heparin-Sepharose and $m$-aminophenylboronic acid agarose chromatographies were chosen for the purification steps. The selection was based on the studies by Uusi-Oukari et al. (19) who showed these chromatographies to be preferential for purifying lipolytic enzymes from postheparin plasma. After the heparin-Sepharose affinity and $m$-aminophenylboronic acid agarose chromatographies the preparation of human milk lipoprotein lipase contained at least two proteins. This preparation is pure enough for immunisation purposes but cannot be used as a calibrator standard in the ELISA assay. Gel filtration, phenyl-Sepharose and the use of a salt gradient (from 0.4 to $2 \mathrm{~mol} / \mathrm{l} \mathrm{NaCl}$ ) in the heparin-Sepharose affinity chromatography failed to separate the lipoprotein lipase protein and contaminating protein present in the $m$-aminophenylboronic acid pool (fig. 1, lane 3). Preparative gel electrophoresis was therefore selected as the final purification method to produce the lipoprotein lipase standard for calibrating the ELISA method. The final preparation contained lipoprotein lipase protein, which reacted well with both polyclonal and monoclonal antihuman lipoprotein lipase antibodies.

Analytical ultracentrifugation studies $(26,27)$ and a study using radiation inactivation (28) of purified lipoprotein lipase obtained from bovine milk indicated that
B

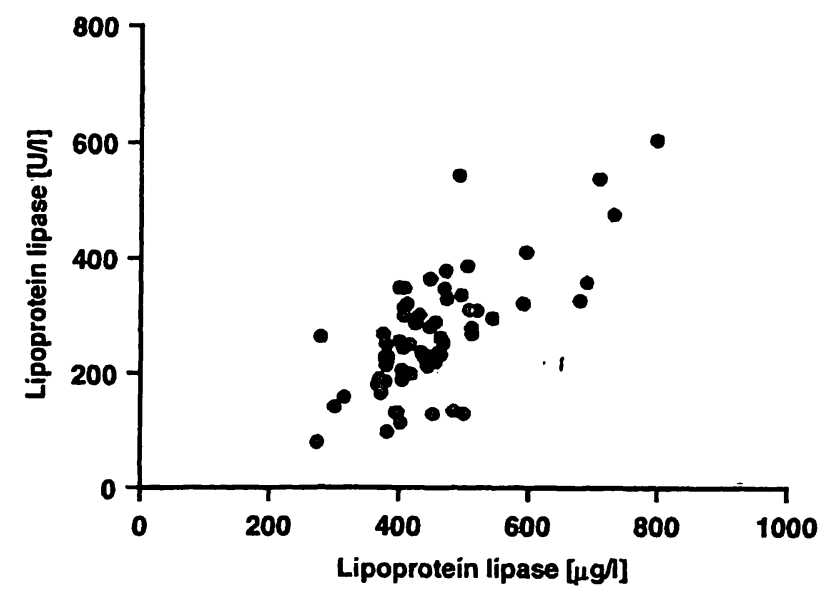

were found in healthy Finnish individuals $(n=66)$ using the ELISA (A) and EIA (B) methods.

the active lipoprotein lipase is a non-covalent homo-dimer glycoprotein (4). To measure total lipoprotein lipase mass concentration, including both monomeric and dimeric protein forms with immunological assays, either two different monoclonal antibodies or a combination of polyclonal and monoclonal antibodies is required. The present ELISA method uses a polyclonal antibody for capture and a monoclonal antibody as a detection antibody. Good sensitivity was achieved down to lipoprotein lipase mass concentrations of $10 \mu \mathrm{g} / \mathrm{l}$. The precision of the ELISA method was also good.

In the healthy Finnish subjects studied, there was a wide range of both lipoprotein lipase activity concentration and mass concentration in postheparin plasma. Both the ELISA method and a commercially available EIA kit for the quantitation of lipoprotein lipase mass concentration in plasma are sensitive; a good correlation existed between lipoprotein lipase activity concentration and mass concentration for both low and high values. The calculated specific activity (U/ $\mu \mathrm{g})$ is therefore uniform, and changes in this property can be used as a good tool to follow certain abnormalities in lipoprotein lipase metabolism.

The different levels in lipoprotein lipase mass concentrations found in two described methods may be due to the different antibodies and/or the primary standardisation of the assay. A relative good correlation between the two assays, however, suggests that the main contributor is a primary standardisation. Lipoprotein lipase protein in the samples, or in the primary or calibrator standards, may change its conformation during storage or thawing. This may have an major effect on the reactivity with anti-lipoprotein lipase antibodies and the shape of calibration curves. In all immunoassays using one or two different monoclonal anti-lipoprotein lipase antibodies, the reference values for postheparin plasma lipoprotein lipase in healthy individuals ranged from 200 to $400 \mu \mathrm{g} / 1$ 
$(11,12,15)$. The assays with a combination of affinitypurified polyclonal and monoclonal antibody, however, measure higher postheparin plasma lipoprotein lipase mass concentrations, the mean values being $800-1000$ $\mu \mathrm{g} / \mathrm{l}((13)$, the present ELISA assay). In the previously described immunoassays $(8-12)$, the primary or calibrator standards were not described in detail, except in the method described by Ideda et al. (15). In addition, the validation of these methods for lipoprotein lipase quantitation was poorly defined. At present, no international

\section{References}

1. Havel RJ, Kane JP, Kashyap ML. Interchange of apolipoproteins between chylomicrons and high density lipoproteins during alimentary lipemia in man. $\mathrm{J}$ Clin Invest 1973; 52:32-8.

2. Nilsson-Ehle PA, Garfinkel AS, Schotz MC. Lipolytic enzymes and plasma lipoprotein metabolism. Annu Rev Biochem 1980; 49:667-93.

3. Taskinen M-R, Kuusi T. Enzymes involved in triglyceride metabolism. Bailliere's Clin Endocrinol Metab 1987; 3:639-66.

4. Braun JEA, Severson DL. Regulation of the synthesis, processing and translocation of lipoprotein lipase. Biochem J 1992; 287:337-47.

5. Eckel RH. Lipoprotein lipase. A multifunctional enzyme relevant to common metabolic diseases. N Engl J Med 1989; 320:1060-8.

6. Olivecrona $T$, Bengtsson-Olivecrona $G$. Lipases involved in lipoprotein metabolism. Curr Opin Lipidol 1990; 1:116-22.

7. Huttunen J, Ehnholm C, Kinnunen P, Nikkilä E. An immunochemical method for the selective measurement of two triglyceride lipases in human postheparin plasma. Clin Chim Acta 1975; 63:335-47.

8. Goldberg IJ, Paterniti JR Jr, France DS, Martinelli G, Cornicelli JA. Production and use of an inhibitory monoclonal antibody to human lipoprotein lipase. Biochim Biophys Acta 1986; 878:168-76.

9. Goers JW, Pedersen ME, Kern PA, Ong J, Schotz C. An enzyme-linked immunoassay for lipoprotein lipase. Anal Biochem 1987; 321:1311-6.

10. Kern PA, Martin RA, Carty J, Goldberg IJ, Ong JM. Identification of lipoprotein lipase immunoreactive protein in pre- and postheparin plasma from normal subjects and patients with type I hyperlipoproteinemia. J Lipid Res 1990; 31:17-26.

11. Babirak SP, Iverius P-H, Fujimoto WY, Brunzell JD. Detection and characterization of the heterozygote state for lipoprotein lipase deficiency. Arteriosclerosis 1989; 9:326-34.

12. Peterson J, Fujimoto Y, Brunzell JD. Human lipoprotein lipase: relationship of activity, heparin affinity, and conformation as studied with monoclonal antibodies. J Lipid Res 1992; 33:1165-70.

13. Tornvall P, Olivecrona G, Karpe F, Hamsten A, Olivecrona T. Lipoprotein lipase mass and activity in plasma and their increase after heparin are separate parameters with different relations to plasma lipoproteins. Arterioscler Thromb Vasc Biol 1995; 15:1086-93.

14. Antikainen $M$, Holmberg $C$, Olivecrona $T$, Bengtsson-Olivecrona $G$, Labeur $C$, Rosseneu $M$, Taskinen M-R. Changes in biological activity and immunoreactive mass of lipoprotein lipase in congenital nephrosis: relationship to hypertriglyceridemia. Eur J Clin Invest 1993; 23:368-74.

15. Ideda Y, Takagi A, Ohkaru Y, Nogi K-I, Iwanaga T, Kurooka $S$, et al. A sandwich-enzyme immunoassay for the quantitation of lipoprotein lipase and hepatic triglyceride lipase in human postheparin plasma using monoclonal antibodies to the corresponding enzymes. J Lipid Res 1990; 31:1911-24. standards exist for lipoprotein lipase, which makes the comparison of results between different assays and laboratories impossible. Present standardisation efforts need to be directed toward removing sources of variability in laboratory methods through the use of certified reference material for calibration. For these reasons, a need for well-defined primary or calibrator standards and reference values is justified for studies in which lipoprotein lipase catalytic activity concentrations and mass concentrations are measured.

16. Tenkanen H, Taskinen M-R, Antikainen M, Ulmanen I, Kontula $\mathrm{K}$, Ehnholm C. A novel amino acid substitution (His $183 \rightarrow G \ln$ ) in exon 5 of the lipoprotein lipase gene results in loss of catalytic activity: phenotypic expression of the mutant gene in a heterozygous state. J Lipid Res 1994; 35:220-8.

17. Antikainen $M$, Tenkanen $H$, Taskinen M-R, Ehnholm C. Mutations affecting human lipoprotein lipase gene. $Z$ Gastroenterol 1995; (3 Suppl):1-3.

18. Zechner R. Rapid and simple isolation procedure for lipoprotein lipase from human milk. Biochim Biophys Acta 1990; 1044:20-5.

19. Uusi-Oukari M, Ehnholm C, Jauhiainen M. Inhibition of hepatic lipase by m-aminophenylboronate. Application of phenylboronate affinity chromatography for purification of human postheparin plasma lipases. J Chromatography 1996; In press.

20. Wessel D, Flugge UI. A method for a quantitative recovery of protein in dilute solution in the presence of detergents and lipids. Anal Biochem 1984; 138:141-3.

21. Laemmli UK. Cleavage of structural proteins during the assembly of the head of bacteriophage T4. Nature 1970; 227:680-5.

22. Towbin H, Staehelin T, Gordon J. Electrophoretic transfer of proteins from polyacrylamide gels to nitrocellulose sheets: procedure and some applications. Proc Natl Acad Sci USA 1979; 76:4350-4.

23. Lowry OH, Rosebrough NJ, Farr AL, Randall RJ. Protein measurement with the Folin phenol reagent. J Biol Chem 1951; 193:265-75.

24. Jensenius JC, Andersen I, Hau J, Crone M, Koch C. Eggs: conveniently packaged antibodies. Methods for purification of yolk IgG. J Immunol Methods 1981; 46:63-8.

25. Affinity chromatography, principles and methods. Technical bulletin from Pharmacia. Uppsala: Ljungföretagen $A B$, 1988:15-8.

26. Osborne JC Jr, Bengtsson-Olivecrona G, Lee NS, Olivecrona T. Studies on inactivation of lipoprotein lipase: role of the dimer to monomer dissociation. Biochemistry 1985; 24:560611.

27. Iverius $\mathbf{P}-\mathrm{H}$, Ostlund-Lindqvist A-M. Lipoprotein lipase from bovine milk. Isolation procedure, chemical characterization, and molecular weight analysis. J Biol Chem 1976; 251:7791-5.

28. Olivecrona T, Bengtsson-Olivecrona G, Osborne JC Jr, Kempner ES. Molecular size of bovine lipoprotein lipase as determined by radiation inactivation. J Biol Chem 1985; 260:6888-91.

Received February, 2/April 17, 1996

Corresponding author: Dr. Marjatta Antikainen, National Public Health Institute, Department of Biochemistry, Mannerheimintie 166, FIN-00300 Helsinki, Finland 


$$
\text { , }
$$

